\title{
KEEFEKTIFAN PROGRAM LITERASI ALQURAN DI SEKOLAH-SEKOLAH SWASTA NON-AGAMA DALAM KERANGKA PENGUATAN KARAKTER (KAJIAN DI JAWA BARAT)
}

\author{
Solehudin \\ UIN Sunan Gunung Djati Bandung \\ Jl. AH. Nasution 105 Cibiru Bandung \\ Email : Suryakancana1991@gmail.com
}

\begin{abstract}
Character education can begin with Qur'anic literacy. It is appropriate to establish a fact-based study in the field, namely in qualitative non-religious schools in West Java, how the character condition of the students who took part in the recitation of the Koran in Non-Religious Private Schools in West Java and knew the character of the students who attended the Koran recitation in these Schools. The purpose of this study was to determine the character conditions of the students who attended the Koran recitation in Non-Religious Private Schools in West Java. The research method used is descriptive analytic with qualitative data types. Data collection techniques using observation, documentation and in-depth interviews. The results of literacy research in non-religious schools in West Java are; first, the method of reading the Koran students who take the Qur'an recitations are in accordance with the Shari'a that is determined, namely: 1) Following adab akhlaqiah reading the Koran, including: a) Ablution before reading the Qur'an, b) Reading ta'awudz when reading the Koran , c) Reading the Koran in a tartil, and d) Trying as much as possible to understand the verse being read. 2) Following the inner adab reading the Koran, including: a) Understanding the meaning of the verses that are read, b) Morals when reading the Koran, c) Hearts that glorify Allah SWT, d) Hearts that elevate the Qur'an, e) Feel that God is speaking. Second, the character condition of male students in Non-Religious Middle Schools in West Java who follow the Qur'anic Study in a spiritual manner is at the level of defamation and outwardly is in an adaptive, communicative and social character. Third, the role of Koran reading towards strengthening the character of students who take part in the Al-Qur'an Recitation is very large and has a positive impact on the condition of students' character.
\end{abstract}

\section{Keywords:}

Literacy; Quran; Non-religious students.

\begin{abstract}
Abstrak
Pendidikan karakter dapat dimulai dengan literasi Alquran. Sangat tepat apabila dibangun suatu penelitian yang berdasarkan pada fakta di lapangan, yaitu di sekolah-sekolah non-agama di Jawa Barat secara kualitatif, bagaimana kondisi karakter para siswa yang mengikuti pengajian Alquran di Sekolah-sekolah Swasta Non-Agama di Jawa Barat dan mengetahui karakter pada siswa yang mengikuti pengajian Alquran di Sekolah-sekolah tersebut. Tujuan penelitian ini adalah untuk mengetahui kondisi karakter para siswa yang mengikuti pengajian Alquran di Sekolahsekolah Swasta Non-Agama di Jawa Barat. Metode penelitian yang digunakan adalah deskriptif analitik dengan jenis data kualitatif. Teknik pengumpulan data menggunakan observasi, dokumentasi dan wawancara mendalam (deep-interview). Hasil penelitian literasi di sekolah-sekolah non agama d Jawa Barat berupa; pertama, Metode membaca Alquran siswa yang mengikuti Pengajian Al-Qur'an sudah sesuai dengan Syariat yang ditentukan, yaitu: 1) Mengikuti adab akhlaqiah membaca Alquran, diantaranya: a) Berwudhu sebelum membaca Alquran, b) Membaca ta'awudz ketika hendak membaca Alquran, c) Membaca Alquran dengan tartil, dan d) Berusaha semampunya untuk memahami ayat yang dibaca. 2) Mengikuti adab batiniah membaca Alquran, diantaranya: a) Memahami arti ayat yang dibaca, b) Akhlak ketika membaca Alquran, c) Hati yang mengagungkan Allah SWT, d) Hati yang menjungjung tinggi Alquran, e) Merasakan bahwa Allah sedang berbicara. Kedua, Kondisi karakter siswa putra di Sekolah Menengah Non-Agama di Jawa Barat yang mengikuti Pengajian Al-Qur'an secara bathiniah berada pada tingkat muthmainnah dan secara lahiriah berada pada kondisi karakter yang adaptif, komunikatif dan sosial. Ketiga, Peran membaca Alquran terhadap penguatan karakter siswa yang mengikuti Pengajian Al-Qur'an sangat besar dan memberikan dampak positif terhadap kondisi karakter siswa.
\end{abstract}

Keywords :

Literasi; Quran; Siswa-non Agama 

Barat)

\section{A. PENDAHULUAN}

Ada upaya-upaya yang dapat dilakukan menuju terciptanya kualitas masyarakat yang maju. Salah satu upaya tersebut adalah memperkuat karakter bagi seluruh lapisan masyarakat dimulai dari sejak dini. Bagi masyarakat Indonesia yang religius, terutama masyarakat Jawa Barat yang religius Islami, pendidikan karakter dapat dimulai dengan literasi Alquran.

Literasi kontemporer merupakan kemampuan seseorang dalam menggunakan informasi tertulis atau cetak untuk mengembangkan pengetahuan, sehingga mendatangkan manfaat bagi masyarakat ${ }^{1}$. Bahkan lebih dari itu, General Director UNESCO, Koichiro Matsura ${ }^{2}$ menjelaskan bahwa literasi lebih dari sekadar membaca dan menulis, melainkan juga mencakup bagaimana kita berkomunikasi dalam masyarakat. Karena literasi berarti juga praktik dan hubungan sosial yang terkait dengan pengetahuan, bahasa dan budaya.

Alquran sendiri merupakan petunjuk bagi umat Islam, bahkan bagi manusia, yang diturunkan Allah SWT melalui Malaikat Jibril kepada Nabi Muhammad SAW. Selain berisi tentang hal-hal keimanan (aqidah), ibadah, dan sejarah; Alquran juga berisi tentang ajaran moral (akhlaq) yang sangat berguna bagi manusia untuk keselamatan mereka di dunia dan di akhirat. Ajaran moral itulah yang kemudian dapat menanamkan karakter pada manusia.

Membaca Alquran menurut keyakinan umat Islam sudah menjadi kewajiban sejak diturunkannya ke dunia ini. Karena dengan membaca Alquran seseorang dapat merasakan ketenangan hati, Allah Swt berfirman, yang artinya: "Ingatlah, hanya dengan mengingat Allah hati menjadi tenang" (QS. Ar-Ra'd:13: 28). Ayat ini menjelaskan bahwa ketenangan hati dapat diraih dengan memabaca Alquran,

\footnotetext{
${ }^{1}$ Kirsch, I.S, “Adult reading practices for work and

${ }^{2}$ Matsuura Koichiro, "Intangible Cultural Heritage was incorporated to Balence The Euro- centrism," t.t.
}

karena semua isi Alquran adalah penyembuh kerisauan hati, sebagaimana termaktub dalam Alquran, "Hai manusia, sesungguhnya telah datang kepadamu pelajaran dari Tuhanmu dan penyembuh bagi penyakit-penyakit (yang berada) dalam dada dan petunjuk serta rahmat bagi orang-orang yang beriman" (QS. Yunus/10: 57).

Alquran adalah pedoman hidup umat manusia, kitab suci yang tidak ada keraguan di dalamnya, bahkan obat dari segala penyakit hati. Sungguh, Alquran adalah mukjizat abadi yang tidak ada tandingannya dalam al-bayan (penjelasan), balaghah (gaya bahasa), itqan (keutuhan), kekokohan dan kekuatan gaya ekspresinya, susunan topik-topiknya, kefasihan perkataannya, keindahan keserasiannya, keteguhan manhajnya, keindahan susunan penyampaiannya, kekayaan kosa katanya, mukjizat yang bersifat ilmiah, kedokteran, hitungan, keterangan halhal gaib, penetaan hukum (kodifikasi hukum). Dengan membacanya dan merenungkannya hati menjadi tenteram.

Dalam kehidupan sehari-hari Alquran sudah jarang dijadikan pedoman hidup umat Islam, karena perkembangan zaman yang pesat menyebabkan manusia lupa akan hakikat yang sebenarnya. Hal itu dapat kita lihat dimana-mana baik melalui media cetak, seperti koran maupun media elektronik seperti televisi. Dunia ini yang penuh dengan praktikpraktik kotor seperti pencurian, pembunuhan, perjudian bahkan mengingkari Alquran itu sendiri seperti sirik, itu karena mereka yang tidak memahami Alquran dengan baik sehingga manifestasi perilakunya menjadi buruk. Betapa banyak dari orang-orang yang fasih membaca Alquran, indah dalam melantunkan setiap ayat, namun miskin dari aktualisasi dan realisasi nilai dari ayat-ayat yang mereka baca ${ }^{3}$. Melainkan tidak semua umat Islam melakukan hal-hal yang keji,

\footnotetext{
${ }^{3}$ Asep S Muhtadi dan Agus Ahmad Safei, Al-Qur'an Kitab Kehidupan, vol. 1 (Bandung: LPTQ ProvinsiJawa Barat, 2004).
} 

Barat)

hanya orang-orang yang beriman dan bertaqwa yang takut kepada Allah, seperti firman-Nya:

"Mukminun dan mukminat, mereka satu samalain pimpin memimpin, mereka menyuruh mengerjakan yang baik, melerang mengerjakan yang salah, tetap mengejakan shalat, dan membayar zakat, dan mereka patuh pada Allah dan Rasul-Nya, itulah orang-orang yang akan diberi rahmat oleh Allah. Sesungguhnya Allah itu maha bijaksana." (QS. Al-Taubah :9:71)

Dalam pandangan Alquran, kondisi masyarakat modern dewasa ini adalah sebuah komunitas yang berada dalam kejahiliyahan. Di mana-mana diselimuti kegelapan, kegelisahan dan berjalan di atas kesesatan. Sebagian jatuh ke jurang kenistaan, sementara yang lain terus bertikai dan bersaing mengejar kekayaan materi. Mereka bagaikan orangorang yang mabuk membabi-buta, berjalan tanpa arah dan tujuan di malam yang kelam. Padahal di hadapannya, ada stop kontak yang berhubungan dengan lampu sorot yang besar. Andaikan mereka mau menggerakkan tangan sedikit saja, tentu bisa saja menyalakan lampu yang akan menerangi kegelapan hati mereka.

Bagi umat Islam, siapapun yang membaca akan meyakini bahwa Alquran bukan hasil karya manusia, dan ia berbeda dengan dari sabda Rasulullah saw. yang terdapat dalam hadits Nabi, meskipun hadits itu diungkapkan dengan tingkat balaghah (kemampuan sastra) yang tinggi. Keberadaan satu ayat Alquran di tengah hadits nabi, menciptakan suatu cahaya tertentu yang dirasakan oleh pembaca dan pendengarnya, sehingga ia mengetahui bahwa redaksi ayat itu bukan bagian dari redaksi yang sebelumnya dan sesudahnya ${ }^{4}$.

Literasi Alquran adalah sebuah perspektif atau cara pandang kita terhadap Alquran dan cara kita menginterpretasi makna dari ayatayat Alquran. Kita membangun sebuah

\footnotetext{
${ }^{4}$ Yusuf al-Qardhawi, Berinteraksi dengan al- Qur'an, trans. oleh Abbdul Hayyie al-Kattan, 1 ed. (Jakarta: Gema Insani Press, 1999).
}

perspektif berdasarkan latar belakang ilmu pengetahuan yang kita miliki. Keahlian yang harus dikembangkan melalui literasi Alquran adalah berpikir bagaimana pentingnya ajaran Alquran dalam menciptakan dan mengendalikan budaya yang membatasi kita dan hidup kita.

Dapat dikatakan bahwa literasi Alquran adalah keahlian yang dapat dipelajari dan dikembangkan. Secara umum literasi Alquran adalah kemampuan individu dalam 'membaca', memahami pesan-pesan yang disampaikan oleh Alquran, serta memahami tujuan-tujuannya, riwayatnya dan ajaranajarannya, termasuk ajaran moral.

Dalam hal literasi secara umum, literasi tidak terlepas dari 3 hal yaitu:

Budaya melek huruf; budaya melek huruf menimbulkan efektivitas dan efisiensi penggunaan simbol-simbol tulisan. Masyarakat dapat mengakumulasi sebuah body of knowledge (bangunan pengetahuan) yang lebih permanen dan mewariskan pengetahuan tersebut ke generasi berikutnya.

Revolusi Gutenberg; dengan ditemukannya mesin cetak oleh Gutenberg pada tahun 1946, maka proses penyampaian informasi menjadi lebih cepat. Informasi menjadi cepat tersebar ke berbagai wilayah yang mengakibatkan kemajuan di berbagai bidang.

Teknologi komunikasi; setiap kemajuan teknologi berpengaruh pada kebudayaan. Munculnya majalah, surat kabar, televisi, radio dan internet telah menciptakan budaya yang berbeda dan beragam di masing-masing daerah.

Berangkat dari penjelasan di atas, tradisi literasi harus benar-benar lekat dalam kehidupan masyarakat. Itu kalau kita ingin mewujudkan kota yang maju dengan masyarakat yang cerdas karena tingkat literasi yang rendah berkaitan erat dengan tingginya tingkat drop out sekolah, kemiskinan dan pengangguran.Ketiga aspek tersebut adalah sebagian dari indikator rendahnya indeks pembangunan manusia. Maka apabila masyarakat tidak siap menerima individuindividu masyarakat yang rendah kualitasnya, 

Barat)

mari kita upayakan sedari dini nuansa kondusif menuju terciptanya budaya keilmuan dalam kehidupan masyarakat, yaitu menciptakan tradisi literasi.Mengiringi tradisi literasi umum tersebut, tradisi literasi Alquran pun sangat perlu bagi umat Islam. Demikian karena banyak hal yang bersifat peribadatan berasal dari Alquran. Sedangkan ibadah itu sendiri banyak yang harus dilakukan secara perorangan, atau apa yang disebut dengan Fardhu 'Ain. Di sinilah perlunya pengajaran Alquran.

Pengajaran Alquran di Indonesia memang mempunyai banyak tempat dan waktu. Ia bisa diajarkan di rumah, di mesjid, di madrasah, ataupun di pesantren. Namun, apabila di sekolah, pengajaran Alquran menjadi sesuatu yang kurang wajib atau kurang mentradisi. Memang ada juga sekolah-sekolah yang berbasis pada agama seperti sekolah-sekolah Muhammadiyah, tetapi banyak juga sekolahsekolah yang tidak berbasis agama sehingga pengajaran Alquran menjadi hal yang langka. Namun begitu, ada kemungkinan besar bahwa terdapat program literasi Alquran pada sekolah-sekolah non-agama tersebut.

Pusat Litbang Lektur dan Khazanah Keagamaan Kementerian Agama telah melakukan penelitian Indeks Literasi Alquran siswa SMA. Dalam skala penilaian 1 sampai 5, penelitian ini menemukan bahwa indeks literasi Alquran siswa SMA secara nasional berada dalam kondisi sedang dengan indeks rata-rata 2,44. Penelitian ini dilakukan terhadap 3.710.069 siswa SMA negeri ataupun swasta dari total populasi siswa SMA sekitar tujuh juta siswa di seluruh Indonesia. Ada empat aspek yang dinilai, yaitu membaca (indeks 2,59) dan menulis (2,2) dimana keduanya masuk kategori sedang. Aspek mengartikan bacaan Alquran berada dalam kategori rendah $(1,87)$, dan aspek menghafal dalam kategori tinggi $(3,03)^{5}$.

\footnotetext{
5 Fuji Pratiwi, "Literasi Alquran Siswa SMA Belum Menggembirakan," Republika, 5 Desember 2016, www.republika.co.id.
}

Penelitian yang dilakukan pada 2016 itu bertujuan mengevaluasi berbagai aspek kemampuan dalam literasi Alquran. Mantan Rektor Institut Ilmu Quran (IIQ) Jakarta Ahsin Sakho Muhammad mengatakan, tingkat literasi Alquran pada siswa SMA nasional yang berada di level sedang, merupakan wajah kelompok pelajar sekolah menengah dalam menggeluti Alquran. Maka, kata dia, perlu dlilihat sejauh mana peran orangtua terhadap anak-anaknya untuk mengaji. Perlu dilihat juga apakah mereka ada di kota atau desa, dekat masjid atau tidak, dan bagaimana peran guru agama di SMA. Karena itu, literasi Alquran perlu digalakkan mulai dari membaca dan mengartikan, sementara menulis di akhir saja. Menurut Ahsin, membaca praktiknya agak mudah. Mengartikan juga tidak perlu keterlibatan jari tangan. Sementara menulis harus menggambar alfabet Arab, menyambungkan huruf, dan sebagainya yang butuh ketekunan sendiri. Ahsin melihat, ini bukan hanya masalah yang berkaitan dengan kebisaan, tapi membangun kedekatan menjadi kecintaaan sehingga nilai Alquran bisa mewarnai kehidupan anak-anak. Ada hubungan Alquran dengan pembentukkan karakter, unsur kecerdasan dan akhlak. ${ }^{6}$

Oleh karena itu, amat tepatlah apabila di sini dibangun suatu penelitian yang berdasarkan pada fakta di lapangan, yaitu di sekolah-sekolah non-agama di Jawa Barat secara kualitatif. Dari latar belakang itulah maka, penelitian ini mengambil tema, "Keefektifan Program Literasi Alquran di Sekolah-sekolah Swasta Non-Agama dalam Kerangka Penguatan Karakter (Kajian di Jawa Barat)."

perumusan masalah yang diturunkan dari judul penelitian tersebut adalah sebagai berikut:pertama, Bagaimana kondisi karakter para siswa yang mengikuti pengajian Alquran di Sekolah-sekolah Swasta Non-Agama di Jawa Barat.Kedua, Bagaimana metode membaca Alquran di Sekolah-sekolah Swasta

\footnotetext{
${ }^{6}$ Fuji Pratiwi.
} 

Barat)

Non-Agama di Jawa Barat.Ketiga, Bagaimana peran membaca Alquran terhadap penanaman karakter pada santri putra yang mengikuti pengajian Alquran di Sekolah-sekolah Swasta Non-Agama di Jawa Barat.

\section{B. HASIL DAN PEMBAHASAN \\ 1. Metodologi Penelitian}

Penelitian ini menggunakan desain pendekatan deskriptif kualitatif. Pendekatan kualitatif memfokuskan telaahnya pada makna-makna subyektif, pengertianpengertian, metafor-metafor, simbol-simbol, dan deskripsi-deskripsi ihwal suatu kasus spesifik yang hendak diteliti. Pendekatan ini dipilih agar studi ini memperolah gambaran detail dan mendalam mengenai suatu gejala sosial tertentu yang bersifat fenomenologis.

Dalam penelitian ini, para peneliti menempatkan diri sebagai the insider yang berusaha sejauh mungkin melakukan empati (atau memproyeksikan diri dalam peran dan persepsi obyek yang diteliti) agar bisa sebaik mungkin merefleksikan penghayatan subyektif dari obyek yang diteliti.

Penelitian ini menggunakan metode studi kasus. Metode studi kasus ialah bentuk penelitian yang mendalam tentang suatu aspek lingkungan sosial termasuk manusia di dalamnya. Studi kasus dapat dilakukan terhadap individu, segolongan manusia, lingkungan hidup manusia atau lembaga sosial. Metode ini dipandang efektif karena mampu digunakan untuk mencari motif-motif dibalik fakta sosial yang tampak secara empirik ${ }^{7}$.

Melalui metode studi kasus, pemaparan yang akan dikemukakan dalam hasil penelitian tidak lain merupakan fakta-fakta yang ditemukan selama penelitian dilakukan dan pemaparan hasil penelitian akan dilakukan secara deskriptif berdasarkan data kualitatif dan kuantitatif yang ada.

\footnotetext{
7 S.Nasution, Berbagai Pendekatan dalam proses Belajar-mengajar (Jakarta: Bumi Aksara, 1982).
}

Unit-unit yang dianalisis dalam kajian ini adalah pengalaman dan opini para stakeholders pendidikan sekolah menengah non-agama di Jawa Barat. Adapun kasus yang diambil adalah para stakeholders di 12 sekolah (6 SMP dan 6 SMA) di enam kabupaten/kota, yaitu Kabupaten Cianjur (SMP Bina Utama Cimacan, SMK Taruna Bhakti di jalan Wiratanudatar), Kabupaten Sumedang (SMP Yadika Tanjungsari-Jatisari, SMK Pemuda di Jalan Raya Sumedang Km.3), Kabupaten Garut (SMP Daya Susila Jln.A.Yani No.36 Garut, Pakuwon, Kec. Garut Kota, SMA Bhakti Putra diKp. Cicariu RT 03/03, Cikarang, Kec. Cisewu)Kabupaten/Kota Tasikmalaya ( SMP Pasundan diJl. Dewi Sartika No.18, Kahuripan, Kec. Tawang, SMK PERIWATASberalamat di Jl. Jend. A. Yani No. 118 Tasikmalaya Lengkongsari Tawang) Kota Cimahi (SMP PGRI 1 Cimahi adalah sekolah tertua di Kota Cimahi yang Berdiri pada tahun Pelajaran Berada di jantung Kota Cimahi, yaitu : Jl. Jend. H. Amir Machmud Gg. PGRI No. 22, SMA Pasundan 2 Cimahi) dan Kota Cirebon (SMP Wahidin Letaknya di Jalan Dr Wahidin S di tengahtengah Kota Cirebon, SMA Widya Utama di Kesambi Baru I No. 55A, Kesambi).

Penelitian ini membutuhkan data yang dikumpulkan dari aktor-aktor kegiatan literasi al-Qur'an yang dilakukan di masing-masing lokasi. Dengan demikian, teknik yang digunakan adalah observasi. Selain itu, juga diwawancarai beberapa pihak yang terkait dengan kegiatan penelitian di tempat tersebut yaitu pihak sekolah, para siswa sendiri, orang tua siswa, dan juga pihak pemerintahan dan masyarakat di kawasan tersebut yang terlibat aktif dalam berbagai kegiatan yang menyangkut literasi al-Qur'an di sekolahsekolah swasta non-agama di Jawa Barat.

Metode pengumpulan data lainnya yang digunakan dalam penelitian ini adalah wawancara mendalam (in-depth interview). Dalam wawancara dengan informan, beberapa informasi yang ditanyakan antara lain: (a) latar belakang pendirian lembaga, (b) kegiatan-kegiatan lembaga, (c) strategi 

Barat)

pengembangan literasi al-Qur'an, dan (d) upaya untuk mempertahankan programprogram lembaga. Triangulasi data menggunakan triangulasi sumber data.

Metode lain adalah kajian dokumen, yaitu menggunakan dokumen-dokumen yang ada di sekolah-sekolah yang dijadikan kajian kasus penelitian.

Validitas dan reliabilitas dalam penelitian kualitatif memiliki spesifikasi tersendiri. Menurut Lincoln dan Guba ${ }^{\wedge}$ paling sedikit ada empat standar atau kriteria utama untuk menjamin keabsahan hasil penelitian kualitatif, dimana dalam penelitian ini dapat diterangkan sebagai berikut: a. standar kredibilitas. b. standar transferabilitas, c. standar dependabilitas, dan d. standar konfirmabilitas.

Analisis data yang digunakan adalah analisis data deskriptif, yang secara umum berupa reduksi data, penyajian data dan penarikan kesimpulan atau verifikasi data. Berdasarkan azas penelitian kualitatif, analisis data dilakukan di lapangan dan bahkan bersamaan dengan proses pengumpulan data. Reduksi data dan sajian data merupakan dua komponen dalam analisis data ${ }^{9}$. Penarikan kesimpulan dilakukan jika pengumpulan data dianggap cukup memadai dan dianggap selesai.

\section{Hasil Penelitian Literasi Alquran di Sekolah Non-Agama di Provinsi Jawabarat}

\section{Metode Membaca Alquran}

Untuk mencapai derajat membaca Alquran yang bisa menjadi pengembang karakter atau tidak hanya seperti membaca koran (tidak membekas di hati) memang bukan sesuatu hal yang mudah paling tidak harus menghayati

\footnotetext{
8 Moleong, Metodologi Penelitian Kualitatif (Bandung: CV. Remaja Rosdakarya, 1998).

9 M.Bamberger, Integrating Quantitative and Qualitative Research in Devlopment Project (Wasington DC: Directions in Devlopment, 2000).
}

setiap kata dan ayat yang terdengar di telinga. Karena tidak semua orang mengerti bahasa Arab, maka dengan tawadlu(rendah diri) sekaligus menyamakan gelombang hati dengan suara Alquran, akan bisa merasakan kelezatan membaca Alquran. Selain itu juga harus mengikuti cara-cara atau metodemetode yang benar sehingga Alquran benarbenar menjadi obat bagi hati yang gundah atau cemas. $^{10}$

MA (Kelas IX)

Subyek yang pertama untuk memperoleh data mengenai metode membaca Alquran siswa putra yang mengikuti pengajian alQur'an adalah MA siswa kelas III SMP. Aspek yang dicari yaitu metode membaca Alquran dan adab bathiniah membaca Alquran.

Untuk observasi ada dua aspek dan empat indikator yang ingin diketahui oleh peneliti mengenai metode membaca Alquran dan adab bathiniah membaca Alquran. Hal ini bertujuan untuk mempermudah mencari jawaban masalah.

\begin{tabular}{|c|c|c|c|c|}
\hline No. & Aspek & $\begin{array}{l}\text { Indikat } \\
\text { or }\end{array}$ & $\underset{f}{\text { Deskripti }}$ & Cheklit \\
\hline \multirow[t]{4}{*}{$\begin{array}{r}1 . \\
111\end{array}$} & \multirow[t]{3}{*}{$\begin{array}{l}\text { Metode } \\
\text { membaca } \\
\text { Alquran }\end{array}$} & Berwudhu & $\begin{array}{l}\text { Subyek } \\
\text { berwudh } \\
\text { u } \\
\text { sebelum } \\
\text { membaca } \\
\text { Alquran }\end{array}$ & $\sqrt{ }$ \\
\hline & & $\begin{array}{l}\text { Membaca } \\
\text { ta'awuz }\end{array}$ & $\begin{array}{l}\text { Subyek } \\
\text { membaca } \\
\text { ta'awudz } \\
\text { sebelum } \\
\text { membaca } \\
\text { Alquran }\end{array}$ & $\sqrt{ }$ \\
\hline & & Tartil & $\begin{array}{l}\text { Subyek } \\
\text { membaca } \\
\text { Alquran } \\
\text { dengan } \\
\text { baik dan } \\
\text { benar }\end{array}$ & $\sqrt{ }$ \\
\hline & $\begin{array}{l}\text { Adab } \\
\text { bathniah } \\
\text { membaca }\end{array}$ & $\begin{array}{l}\text { Memahami } \\
\text { kandungan } \\
\text { ayat yang }\end{array}$ & $\begin{array}{l}\text { Subyek } \\
\text { mengerti } \\
\text { dan }\end{array}$ & $\sqrt{ }$ \\
\hline
\end{tabular}

${ }^{10}$ Maulana Muhammad Zakariyya al-Kandhalawi, Fadhail Amal (Bandung: Pustaka Ramadhan, 2001), 338 . 


\begin{tabular}{|l|l|l|l|l|}
\cline { 2 - 4 } & Alquran & $\begin{array}{l}\text { faham } \\
\text { arti dari } \\
\text { ayat yang } \\
\text { dibaca }\end{array}$ & \\
\hline
\end{tabular}

Tabel 1 Variabel: Metode Membaca Alquran

Hasil observasi di lapangan menunjukkan bahwa kedua aspek tersebut terjawab oleh subyek MA. Hal ini dapat kita lihat pada tabel observasi di atas. Subyek MA memenuhi kriteria yang diujikan oleh peneliti. Hal ini tentunya memberikan kemudahan untuk meraih kehebatan karakter dan hati karena subyek mengikuti syariat yang telah ditentukan. Pertama, berwudhu sebelum membaca Alquran hal itu bertujuan untuk menjaga kesucian Alquran, kedua, membaca ta'awudz ketika hendak membaca Alquran hal itu bertujuan untuk menjaga diri dari godaan jin dan setan. Ketiga, membaca Alquran dengan baik dan benar, baik dari segi makharijul hurf maupun tajwidnya, hal itu bertujuan untuk menghindar dari kesalahan dan dosa. Dan yang keempat, mengerti dan faham arti dari ayat yang dibaca, hal itu bertujuan untuk memahami maksud dari ayat tersebut dan memaknai untuk dicerna oleh hati.

Adapun aspek yang ingin diuji oleh peneliti dengan menggunakan metode wawancara berjumlah dua, yaitu aspek metode membaca Alquran dan adab bathiniah membaca Alquran.

\begin{tabular}{|c|c|c|c|c|}
\hline $\mathrm{N}$ & Aspek & $\begin{array}{l}\text { Sub } \\
\text { Aspek }\end{array}$ & $\begin{array}{l}\text { Pertanya } \\
\text { an }\end{array}$ & Respon \\
\hline 1 & $\begin{array}{l}\text { Metode } \\
\text { membac } \\
\text { a } \\
\text { Alquran }\end{array}$ & $\begin{array}{l}\text { Membaca } \\
\text { ta'awudz }\end{array}$ & 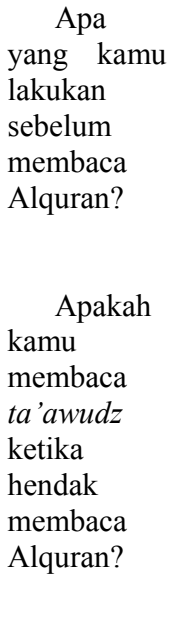 & $\begin{array}{l}\text { Membersi } \\
\text { hkan dari } \\
\text { hadats kecil } \\
\text { (berwudhu), } \\
\text { membaca } \\
\text { ta'awudz dan } \\
\text { membaca } \\
\text { basmalah. } \\
\text { Tentu, } \\
\text { karena kita } \\
\text { berlindung } \\
\text { kepada Allah } \\
\text { swt. dari } \\
\text { gangguan } \\
\text { setan agar kita } \\
\text { khusyuk } \\
\text { ketika }\end{array}$ \\
\hline
\end{tabular}

\begin{tabular}{|c|c|c|c|c|}
\hline & & & \begin{tabular}{l}
\multicolumn{1}{c}{ Apakah } \\
kamu \\
membaca \\
Alquran \\
dengan baik \\
dan benar?
\end{tabular} & \begin{tabular}{l} 
membaca \\
Alquran. \\
\multicolumn{1}{c}{ Insya } \\
Allah, karena \\
itu sangat \\
dianjurkan \\
dan mendapat \\
pahala jika \\
kita \\
membacanya \\
dengan baik \\
dan benar.
\end{tabular} \\
\hline 2 & $\begin{array}{l}\quad \text { Ada } \\
\text { b } \\
\text { batiniah } \\
\text { membac } \\
\text { a } \\
\text { Alquran }\end{array}$ & 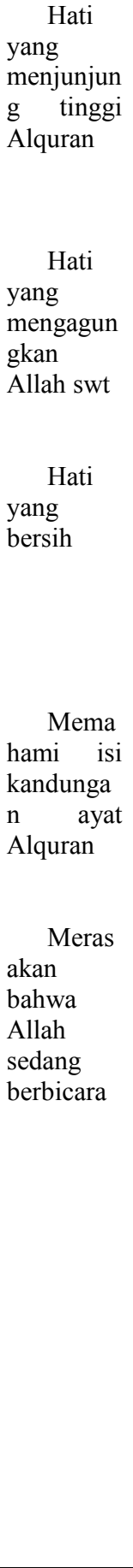 & $\begin{array}{l}\quad \text { Bagaima } \\
\text { na hatimu } \\
\text { ketika } \\
\text { sedang } \\
\text { membaca } \\
\text { Alquran? } \\
\\
\\
\quad \\
\quad \text { Bagaima } \\
\text { natimu } \\
\text { kepada } \\
\text { Allah ketika } \\
\text { sedang } \\
\text { membaca } \\
\text { Alquran? } \\
\\
\quad \text { Apakah } \\
\text { kamu ikhlas } \\
\text { ketika } \\
\text { membaca } \\
\text { Alquran? } \\
\text { kenadamu? }\end{array}$ & 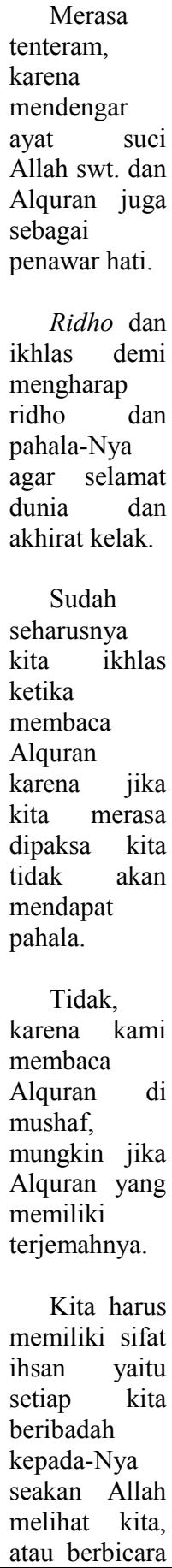 \\
\hline
\end{tabular}



Barat)

\begin{tabular}{|l|l|l|l|l|}
\hline & & & $\begin{array}{l}\text { kepada kita } \\
\text { melalui ayat- } \\
\text { Nya. }\end{array}$ \\
\hline
\end{tabular}

Tabel 2 Variabel: Metode Membaca Alquran

MA siswa putra yang duduk di bangku kelas III SMP ini mengatakan bahwa sebelum membaca Alquran ia selalu membersihkan diri dari hadats kecil dan membaca ta'awudz.Hal itu bertujuan untuk menjaga kesucian Alquran dan menghindari dari godaan jin dan setan yang senantiasa mengganggu umat manusia ketika hendak beribadah. Makna ta'awudz ialah meminta perlindungan dari godaan jin dan setan, sehingga membaca Alqurannya menjadi tenang dan khusyuk. Kemudian subyek juga membaca Alquran dengan baik dan benar (tartil), tentunya untuk menghindari dari kesalahan dan dosa yang disengaja agar membaca Alquran bukan menjadi sia-sia serta enak didengar oleh orang di sekitarnya. Ketika subyek ditanya arti dari ayat yang dibaca, ia mampu mengartikan sebagian ayat yang dibaca. Tentunya hal tersebut menjadi nilai tambah untuk memaknai dan merenungi maksud dan tujuan dari ayat yang dibaca. Selain itu, di pondok juga diajarkan nahwu dan sharaf yang memiliki fungsi untuk mentafsirkan maknanya dengan baik dan benar, oleh karena itu subyek sedikitnya mampu memahami arti dari sebagian ayat yang dibaca.

\section{AS (Kelas IX)}

Subyek yang kedua untuk memperoleh data mengenai metode membaca Alquran siswa putra yang mengikuti pengajian al-Qur'an adalah AS siswa kelas III SMP. Aspek yang dicari yaitu metode membaca Alquran dan adab bathiniah membaca Alquran.

Untuk observasi ada dua aspek dan empat indikator yang ingin diketahui oleh peneliti mengenai metode membaca Alquran dan adab bathiniah membaca Alquran. Hal ini bertujuan untuk mempermudah mencari jawaban masalah.

Hasil observasi di lapangan menunjukkan bahwa kedua aspek tersebut terjawab oleh subyek AS. Hal ini dapat kita lihat pada tabel observasi di atas. Subyek AS memenuhi kriteria yang diujikan oleh peneliti. Hal ini tentunya memberikan kemudahan untuk meraih ketenangan jiwa dan hati karena subyek mengikuti syariat yang telah ditentukan seperti. Pertama, berwudhu sebelum membaca Alquran hal itu bertujuan untuk menjaga kesucian Alquran, kedua, membaca ta'awudz ketika hendak membaca Alquran hal itu bertujuan untuk menjaga diri dari godaan jin dan setan. Ketiga, membaca Alquran dengan baik dan benar, baik dari segi makharijul hurf maupun tajwidnya. Hal itu bertujuan untuk menghindar dari kesalahan dan dosa. Dan yang keempat, mengerti dan faham arti dari ayat yang dibaca. Hal itu bertujuan untuk memahami maksud dari ayat tersebut dan memaknai untuk dicerna oleh hati.

Adapun aspek yang ingin diuji oleh peneliti dengan menggunakan metode wawancara berjumlah dua, yaitu aspek metode membaca Alquran dan adab bathiniah membaca Alquran.

Kemudian ungkapan dari subyek AS siswa kelas III SMP (IX) mengatakan bahwa sebelum membaca Alquran subyek mengambil air wudhu kemudian bershalawat kepada Nabi Muhammad Saw. Hal itu bertujuan untuk menjaga kesucian Alquran dan menghindari dari godaan jin dan setan yang senantiasa mengganggu umat manusia ketika hendak beribadah. Makna ta'awudz ialah meminta perlindungan dari godaan jin dan setan, sehingga membaca Alquran-nya menjadi tenang dan khusyuk. Kemudian subyek juga membaca Alquran dengan baik dan benar (tartil), tentunya untuk menghindari dari kesalahan dan dosa yang disengaja agar membaca Alquran bukan menjadi sia-sia serta enak didengar oleh orang di sekitarnya.

Ketika membaca Alquran subyek mengatakan bahwa hatinya menjadi tenang dan tentunya membaca Alquran tidak ada paksaan sama sekali atau subyek merasa ikhlas dan hatinya terpaut kepada Allah ketika membaca Alquran. Namun sayangnya subyek tidak mampu mengartikan arti dari ayat yang 

Barat)

dibaca, sehingga menyulitkan untuk mengetahui maksud dan tujuan dari ayat yang dibacanya kecuali melalui Alquran dan terjemahannya.

\section{a. NS (Kelas IX)}

Subyek yang ketiga untuk memperoleh data mengenai metode membaca Alquran siswa putra yang mengikuti pengajian al-Qur'an adalah NS siswa kelas III SMP (IX). Aspek yang dicari yaitu metode membaca Alquran dan adab bathiniah membaca Alquran.

Untuk observasi ada dua aspek dan empat indikator yang ingin diketahui oleh peneliti mengenai metode membaca Alquran dan adab bathiniah membaca Alquran. Hal ini bertujuan untuk mempermudah mencari jawaban masalah.

Hasil observasi di lapangan menunjukkan bahwa kedua aspek tersebut tidak terjawab secara keseluruhan oleh subyek NS. Hal ini dapat kita lihat pada tabel observasi di atas. Subyek NS tidak memenuhi kriteria yang diujikan oleh peneliti. Hal ini tentunya agak sulit untuk mendapatkan penumbuhan karakter karena subyek tidak mengikuti keempat syariat yang telah ditentukan seperti. Pertama, berwudhu sebelum membaca Alquran hal itu bertujuan untuk menjaga kesucian Alquran, kedua, membaca ta'awudz ketika hendak membaca Alquran hal itu bertujuan untuk menjaga diri dari godaan jin dan setan. Ketiga, membaca Alquran dengan baik dan benar, baik dari segi makharijul hurf maupun tajwidnya, hal itu bertujuan untuk menghindar dari kesalahan dan dosa. Dan yang keempat, subyek tidak mengerti dan faham arti dari ayat yang dibaca, hal itu tentu membuat subyek merasakan dampaknya dalam memahami arti ayat yang dibaca.

Adapun aspek yang ingin diuji oleh peneliti dengan menggunakan metode wawancara berjumlah dua, yaitu aspek metode membaca Alquran dan adab bathiniah membaca Alquran.

Subyek yang ketiga bernama NS siswa yang masih duduk di bangku kelas III SMP mengatakan bahwa ia sebelum membaca Alquran sudah mengambil air wudhu, hal itu bertujuan untuk menjaga kesucian Alquran. Setelah itu ia mengatakan bahwa ketika hendak membaca Alquran selalu dimulai dengan ta'awudz agar kita dijauhkan dari godaan setan. Ketika sedang membaca Alquran merasa hatinya sejuk apalagi sampai mendengar qira'at dan mujawwad.

Kondisi hati subyek ketika membaca Alquran dalam keadaan tenang dan mengingat Allah Swt. tentunya hal tersebut harus didasari dengan keikhlasan hati agar merasa tenteram. Namun sayangnya subyek belum bisa memahami ayat Alquran yang dibaca sehingga aktivitas membaca Alquran hanya terasa kegiatan yang biasa, padahal yang sebenarnya Allah sedang berkomunikasi dengan hambaNya yang sedang membaca Alquran.

\section{DN (Kelas X)}

Subyek yang keempat untuk memperoleh data mengenai metode membaca Alquran siswa putra yang mengikuti pengajian alQur'an adalah DN siswa kelas I SMA. Aspek yang dicari yaitu metode membaca Alquran dan adab bathiniah membaca Alquran.

Untuk observasi ada dua aspek dan empat indikator yang ingin diketahui oleh peneliti mengenai metode membaca Alquran dan adab bathiniah membaca Alquran. Hal ini bertujuan untuk mempermudah mencari jawaban masalah.

Hasil observasi di lapangan menunjukkan bahwa kedua aspek tersebut terjawab oleh subyek DN. Hal tersebut dapat dilihat pada tabel observasi di atas. Subyek DN memenuhi kriteria yang diujikan oleh peneliti. Hal ini tentunya memberikan kemudahan untuk menumbuhkan karakter dan hati karena subyek mengikuti syariat yang telah ditentukan seperti. Pertama, berwudhu sebelum membaca Alquran hal itu bertujuan untuk menjaga kesucian Alquran, kedua, membaca ta'awudz ketika hendak membaca Alquran hal itu bertujuan untuk menjaga diri dari godaan jin dan setan. Ketiga, membaca Alquran dengan baik dan benar, baik dari segi makharijul hurf maupun tajwid-nya. Hal itu bertujuan untuk menghindar dari kesalahan dan dosa. Dan yang keempat, mengerti dan 

Barat)

faham arti dari ayat yang dibaca, hal itu bertujuan untuk memahami maksud dari ayat tersebut dan memaknai untuk dicerna oleh hati.

Adapun aspek yang ingin diuji oleh peneliti dengan menggunakan metode wawancara berjumlah dua, yaitu aspek metode membaca Alquran dan adab bathiniah membaca Alquran.

Subyek yang keempat bernama DN siswa kelas I SMA mengatakan bahwa sebelum membaca Alquran subyek membaca ta'awudz dan ber-shalawat. Hal itu bertujuan untuk menghindari dari godaan setan yang senantiasa mengganggu manusia ketika sedang beribadah kepada Allah. Untuk bacaannya subyek mengatakan masih banayk yang salah. Hal ini tentunya disebabkan oleh kurangnya intensitas belajar membaca Alquran. Kemudian subyek merasa senang ketika membaca Alquran dan pikirannya fokus pada bacaan Alquran, maka implikasi dari hal itu subyek merasa senang dan tenang. Namun untuk merasa bahwa membaca Alquran itu media untuk berkomunikasi dengan Allah pernah merasakannya pada saat sedang khusyuk membacanya. Hal tersebut tentunya disebabkan oleh kemampuan subyek yang belum mengerti arti dari ayat Alquran yang dibacanya secara keseluruhan.

SQ (Kelas X)

Subyek yang kelima untuk memperoleh data mengenai metode membaca Alquran siswa putri yang mengikuti pengajian alQur'an adalah SQ siswi kelas I SMA. Aspek yang dicari yaitu metode membaca Alquran dan adab bathiniah membaca Alquran.

Untuk observasi ada dua aspek dan empat indikator yang ingin diketahui oleh peneliti mengenai metode membaca Alquran dan adab bathiniah membaca Alquran. Hal ini bertujuan untuk mempermudah mencari jawaban masalah.

Hasil observasi di lapangan menunjukan bahwa kedua aspek tersebut tidak terjawab secara keseluruhan oleh subyek SQ yang memang hal ini dapat kita lihat pada tabel observasi di atas. Subyek SQ tidak memenuhi kriteria yang diujikan oleh peneliti. Hal ini tentunya agak sulit untuk mendapatkan kerenangan karakter dan hati karena subyek tidak mengikuti keempat syariat yang telah ditentukan seperti. Pertama, berwudhu sebelum membaca Alquran hal itu bertujuan untuk menjaga kesucian Alquran, kedua, membaca ta'awudz ketika hendak membaca Alquran hal itu bertujuan untuk menjaga diri dari godaan jin dan setan. Ketiga, membaca Alquran dengan baik dan benar, baik dari segi makharijul hurf maupun tajwidnya, hal itu bertujuan untuk menghindar dari kesalahan dan dosa. Dan yang keempat, subyek tidak mengerti dan faham arti dari ayat yang dibaca, hal itu tentu membuat subyek merasakan dampaknya dalam memahami arti ayat yang dibaca.

Adapun aspek yang ingin diuji oleh peneliti dengan menggunakan metode wawancara berjumlah dua, yaitu aspek metode membaca Alquran dan adab bathiniah membaca Alquran.

Untuk hasil yang kelima diperoleh dari subyek yang bernama SQ siswa kelas I SMA, ia mengatakan bahwa sebelum membaca Alquran sudah dalam kondisi sudah berwudhu hal itu bertujuan untuk menjaga kesucian Alquran atau melakukan shalat dua raka'at agar hatinya menjadi tambah tenteram. Kemudian subyek memulainya dengan ta'awudz dengan kondisi hati yang begitu tenang hal tersbut guna menghindari dari gangguan jin dan setan yang senantiasa menjerumuskan manusia ketika hendak beribadah kepada Allah. Kemudian subyek mengatakan hatinya hanya ingin mengharap ridho Allah dengan membaca Alquran dengan penuh keikhlasan. Namun subyek terkadang memahami arti dari ayat yang dibacanya dan juga tidak, hal tersebut menyebabkan ia tidak pernah merasakan bahwa ketika membaca Alquran itu Allah sedang berkomunikasi dengan hamba-Nya.

\section{Karakter Siswa}

Penelitian ini mengambil sampel 5 siswa dari populasi 12 siswa SMP/SMA yang diwawancarai secara mendalam dalam 
penelitian ini untuk melihat implikasi dari intensitas membaca Alquran yang paling banyak.

Sesuai dengan metode yang digunakan untuk memperoleh data yaitu metode observasi yang bertujuan untuk melihat dan menelaah kondisi yang terjadi di lokasi penelitaian dan metode wawancara yang bertujuan untuk mengetahui lebih dalam jawaban dari masalah penelitian ini yang nantinya dapat menjawab hasil dari penelitian ini.

\section{a. M (Kelas VII)}

Subyek yang pertama untuk memperoleh data mengenai kondisi karakter siswa putra yang mengikuti pengajian al-Qur'an adalah MU. Aspek yang dicari yaitu aspek bathiniah dan lahiriah subyek.

Kedua aspek tersebut sangat penting untuk diketahui karena menyangkut perilaku yang terlihat secara kasat mata, sehingga kondisi penjiwaan siswa yang mengikuti pengajian alQur'an dapat dikatakan tenang. Di bawah ini tabel percakapan antara peneliti dengan subyek yang diteliti.

\begin{tabular}{|c|c|c|c|c|}
\hline $\begin{array}{l}\mathrm{N} \\
\mathrm{O}\end{array}$ & Aspek & $\begin{array}{l}\text { Sub } \\
\text { Aspek }\end{array}$ & $\begin{array}{l}\text { Perta } \\
\text { nyaan }\end{array}$ & Respon \\
\hline 1 & $\begin{array}{l}\text { Batinia } \\
h\end{array}$ & $\begin{array}{l}\text { Nafs } \\
\text { Muthmainnah } \\
\text { yang karakter } \\
\text { mengajak } \\
\text { kembali } \\
\text { kepada fitrah } \\
\qquad \text { Nafs } \\
\text { Radiyah, } \\
\text { karakter yang } \\
\text { menerima } \\
\text { ketentuan } \\
\text { yang Allah } \\
\text { berikan } \\
\quad \text { Nafs } \\
\text { Mardiyah, } \\
\text { karakter yang } \\
\text { meninggalkan } \\
\text { segala kecuali } \\
\text { Allah }\end{array}$ & \begin{tabular}{l}
\multicolumn{1}{c}{ Pern } \\
ahkah \\
kamu \\
mengajak \\
membaca \\
Alquran \\
kepada \\
teman \\
kamu? \\
$\quad$ Baga \\
imana \\
perasaan \\
mu \\
ketika \\
harapanm \\
u tidak \\
sesuai \\
dengan \\
kenyataa \\
n?
\end{tabular} & $\begin{array}{l}\quad \begin{array}{l}\text { Jarang } \\
\text { semaunya merena } \\
\text { saja. }\end{array} \\
\text { Hanya } \\
\text { bertawakkal kepada } \\
\text { Allah dan qona'ah } \\
\text { menyerahkan } \\
\text { segalanya untuk } \\
\text { yang terbaik. } \\
\text { Nabi } \\
\text { Muhammad Saw. } \\
\text { sebagai suri tauladan } \\
\text { manusia dan tokoh- } \\
\text { tokoh ternama untuk } \\
\text { diikuti sebagai } \\
\text { manusia. }\end{array}$ \\
\hline 2 & $\begin{array}{r}L a \\
\text { hiriah }\end{array}$ & \begin{tabular}{l}
\multicolumn{1}{c}{ Mampu } \\
menyesuaikan \\
diri
\end{tabular} & $\begin{array}{l}\quad \text { Apa } \\
\text { yang } \\
\text { kamu } \\
\text { lakukan } \\
\text { ketika }\end{array}$ & \begin{tabular}{lr}
\multicolumn{2}{c}{ Berinteraksi } \\
dengan & lingkungan \\
dan & mengajak \\
terhadap kebaikan.
\end{tabular} \\
\hline
\end{tabular}

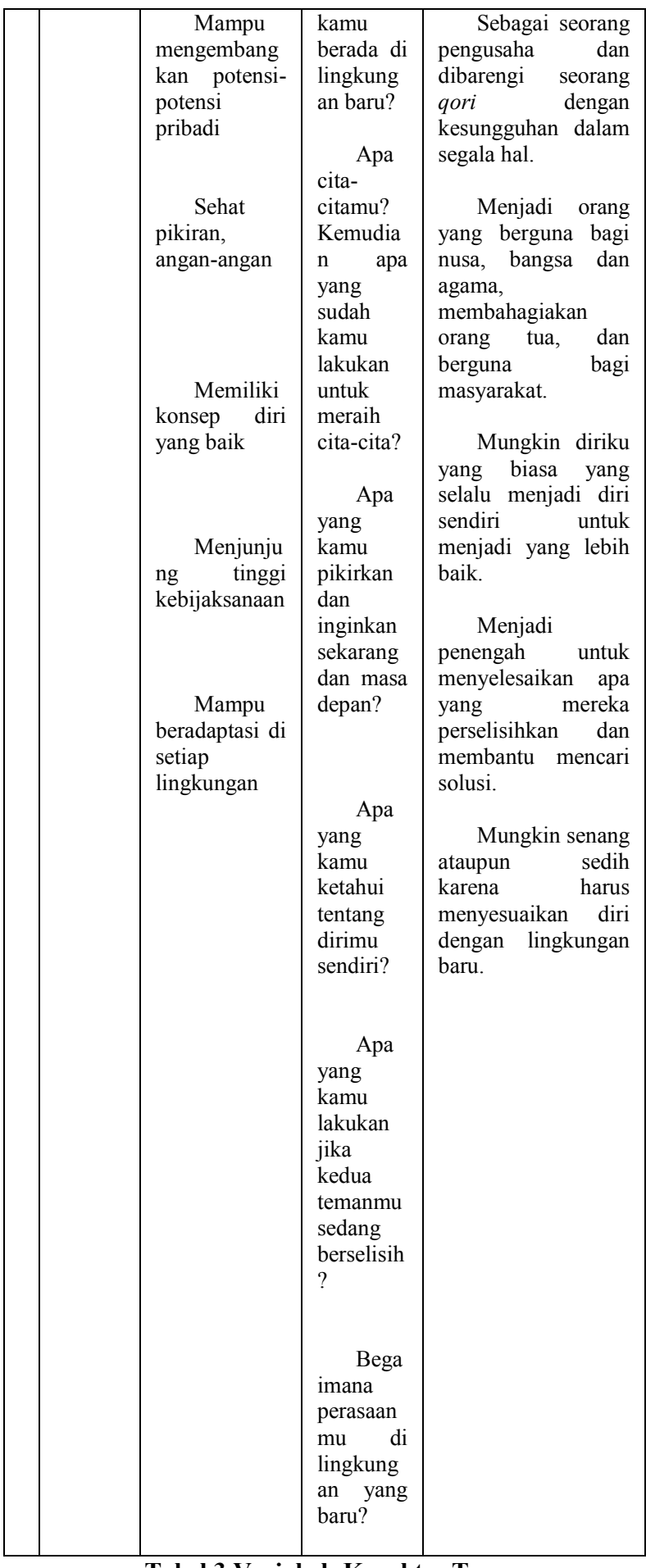

Tabel 3 Variabel: Karakter Tenang

Berdasarkan hasil dari wawancara yang dilakukan oleh peneliti kepada saudara MU mengatakan bahwa dia kadang mengajak temannya untuk membaca Alquran, karena membaca Alquran adalah salah satu cara untuk menumbuhkan karakter dan berinteraksi dengan Allah Swt agar menjadi hamba yang 

Barat)

taat dan bertaqwa. Selain itu, dia mampu menerima ketentuan Allah yang tidak sesuai harapannya yang belum tentu semua orang bisa menanganinya. Hal ini diperkuat oleh pengertian karakter yang ridho (radhiyah) sebagai karakter yang senantiasa menerima yang Allah takdirkan kepada semua orang. Namun sayangnya untuk mencapai karakter yang diridhoi (mardhiyah) tentu ini kehendak Allah Swt. penjelasan berikut adalah ciri dari karakter yang tenang secara bathiniah.

Adapun ciri-ciri karakter yang tenang secara lahiriah yaitu ditandai dengan sikap atau perilaku yang dapat diterima oleh masyarakat atau tidak menyimpang. MU tahu bahwa ia mampu menyesuaikan diri di lingkungan yang baru dan mampu mengontrol dirinya. Ini menandakan bahwa subyek MU memiliki karakter yang tenang. Selain itu pula dia mampu mengembangkan potensi dirinya dengan cara memiliki cita-cita yang logis dan memiliki sikap yang bijaksana.

\section{b. A Y (Kelas IX)}

Subyek yang kedua untuk memperoleh data mengenai kondisi karakter siswa putra yang mengikuti pengajian al-Qur'an adalah AY siswa kelas III SMP. Aspek yang dicari yaitu aspek bathiniah dan lahiriah subyek.

Di bawah ini tabel percakapan antara peneliti dengan subyek SMP/SMA swasta non agama di Jawa Barat.

Adapun hasil yang kedua yang didapatkan dari saudara AY bahwa dia pernah mengajak temannya untuk membaca Alquran karena dia mengungkapkan bahwa kegiatan membaca Alquran di SMP tersebut sudah menjadi agenda rutin namun di sela-sela waktu di luar jadwal rutin dia hanya pernah sesekali mengajak temannya. Selain itu pula AS merasa sedikit kecewa jika harapannya tidak sesuai dengan kenyataan. Itu artinya bahwa kondisi karakter AY secara batiniah masih belum relatif stabil.

\section{c. N I (Kelas IX)}

Subyek yang ketiga untuk memperoleh data mengenai kondisi karakter siswa putra yang mengikuti pengajian al-Qur'an adalah NI siswa kelas III SMP. Aspek yang dicari yaitu aspek bathiniah dan lahiriah subyek. Kedua aspek tersebut sangat penting untuk diketahui karena menyangkut perilaku yang terlihat, sehingga kondisi penjiwaan siswa dapat dikatakan tenang jika sesuai dengan teori yang telah dijelaskan.

Untuk hasil yang ketiga didapatkan dari subjek yang bernama NI yang sedang duduk di bangku kelas III, ia mengatakan bahwa pernah mengajak temannya untuk membaca Alquran karena itu merupakan kebaikan dalam mengajak kebaikan. Namun ia memiliki sikap yang labil dalam perihal pencapaian atau harapan yang tidak sesuai dengan kenyataannya. Hal tersebut diungkapkannya dengan merasa frustasi dan turun mental, tetapi ia mencoba untuk merubah keadaan. Dapat disimpulkan bahwa kondisi bathiniah NI masih di tataran karakter muthmainnah dan relatif stabil.

Secara lahiriah sikap atau mental NI dapat dikatakan baik, hal ini dapat diperkuat dari hasil wawancara peneliti dengan subyek yang bernama NI bahwa ia memiliki kemampuan untuk beradaptasi di lingkungan yang baru dan memiliki perasaan yang tenang jika dihadapkan dengan lingkungan baru. Kemudian, ia memiliki konsep diri yang lumayan baik dan cita-cita yang sangat mulia.

D K (Kelas X)

Subyek yang keempat untuk memperoleh data mengenai kondisi karakter siswa putra yang mengikuti pengajian Alquran adalah DK siswa kelas I SMA. Aspek yang dicari yaitu aspek bathiniah dan lahiriah subyek. Kedua aspek tersebut sangat penting untuk diketahui karena menyangkut perilaku yang terlihat oleh kasat mata, sehingga kondisi penjiwaan siswa yang mengikuti pengajian Alquran dapat dikatakan tenang.

Untuk hasil yang keempat yang diperoleh dari subyek yang bernama DK yang masih duduk di bangku kelas I SMA, ia mengungkapkan pernah mengajak temannya membaca Alquran, dan ia akan merasa sakit hati jika harapannya tidak sesuai dengan kenyataan. Hal ini tentunya ia memiliki sikap 

Barat)

yang relatif stabil namun tidak menutup kemungkinan akan merasakan ketidaktenangan karena secara bathiniah ia masih belum memiliki sikap tenang.

Secara lahiriah ia memiliki sikap keraguraguan jika berada di lingkungan yang baru, hal ini berdasarkan ungkapannya yang mengatakan merasa ragu-ragu karena belum terbiasa. Kemudian subyek juga akan memiliki perasaan yang sama (ragu-ragu) jika berada di lingkungan baru. Subyek pun memiliki citacita yang masih abstrak dan belum jelas entah akan menjadi apa kelak nanti. Hal ini berdasarkan ungkapannya bahwa subyek akan menjadi orang yang digunakan di masyarakat. Tentunya itu merupakan cita-cita yang masih belum jelas dan perlu dikonkretkan lagi. Kemudian subyek memiliki konsep diri yang baik, dan pikiran yang baik.

\section{d. H (Kelas X)}

Subyek yang kelima untuk memperoleh data mengenai kondisi karakter siswa putri yang mengikuti pengajian al-Qur'an adalah HA siswi kelas I SMA. Aspek yang dicari yaitu aspek bathiniah dan lahiriah subyek. Kedua aspek tersebut sangat penting untuk diketahui karena menyangkut perilaku yang terlihat oleh kasat mata, sehingga kondisi penjiwaan siswa yang mengikuti pengajian alQur'an dapat dikatakan tenang jika sesuai dengan teori yang telah dijelaskan.

Untuk hasil yang kelima didapatkan dari subyek yang bernama HA siswa yang masih duduk di bangku kelas I SMA ia mengatakan bahwa subyek pernah dan sering mengajak temannya untuk membaca Alquran, kemudian subyek memiliki sikap dan mental yang luar biasa yang mampu menerima takdir yang tidak sesuai dengan harapannya. Ini artinya secara bathiniah subyek memiliki karakter yang tenang dan stabil, sehingga sangat besar peluang subyek untuk meraih kondisi karakter yang diridhoi (mardhiyah).

Secara lahiriah subyek memiliki sikap dan mental yang baik karena ia mampu menyesuaikan diri di lingkungan yang baru, kemudian perasaannya pun demikian. Subyek yang bernama HA ini memiliki cita-cita yang baik dengan ingin menjadi seorang Duta Besar dan untuk mencapainya subyek belajar dengan giat. Selain memiliki cita-cita yang baik subyek juga memiliki konsep diri yang baik dengan mengatakan bahwa ini adalah diri saya dengan segala kekurangan dan kelebihan yang diberikan Allah swt. Oleh karena itu secara lahiriah kondisi penjiwaan subyek yang berinisial HA dapat dikatakan tenang.

\section{Peran Membaca Alquran terhadap Karakter}

Membaca Alquran bagi siswa merupakan hal yang umum dilakukan, namun apabila membaca al-Qur ${ }^{\text {ee }}$ an serta memahami makna ayat yang dibaca dan dibaca secara terusmenerus memang sulit. Imam AL-Ghazali dalam kitabnya Ihya Ulumuddin berpendapat bahwa makna membaca Alquran adalah dengan memadukan peran lisan, akal, dan hati. Adapun peran lisan adalah untuk memperbaiki tajwid dan makhrojul huruf, peran akal berupa memahami makna yang terkandung di dalam setiap ayatnya, dan peran hati adalah dengan menghayati nada-nada Alquran, mengambil pelajaran serta menimbulkan pembekasan dalam hati. ${ }^{11}$ Berdasarkan penelitian yang peneliti lakukan di lapangan dengan metode observasi dan interview seperti dapat dipaparkan dalam laporan berikut.

Hamdan (Kelas IX)

Subyek yang pertama untuk memperoleh data mengenai fadhilah membaca Alquran siswa putra yang mengikuti pengajian alQur'an adalah HD siswa kelas III SMP. Aspek yang dicari yaitu keutamaan (fadhilah) membaca Alquran.

Untuk observasi ada satu aspek dan tiga indikator yang ingin diketahui oleh peneliti mengenai fadhilah membaca Alquran. Hal ini bertujuan untuk mempermudah mencari jawaban masalah.

\begin{tabular}{|l|l|l|l|l|}
\hline $\begin{array}{l}\mathbf{N} \\
\mathbf{0}\end{array}$ & Aspek & Indikat & Deskriptif & $\begin{array}{l}\text { Chekl } \\
\text { ist }\end{array}$ \\
\hline
\end{tabular}

11 Nur Subhan, Energi Ilahi Tilawah (Jakarta: Republika, 2012), 4. 


\begin{tabular}{|c|c|c|c|}
\hline \multirow[t]{3}{*}{$\begin{array}{l}\text { Fadilah } \\
\text { membaca } \\
\text { Alquran }\end{array}$} & \begin{tabular}{l}
\multicolumn{1}{c}{ Dapat } \\
memecahka \\
$\mathrm{n}$ masalah \\
kehidupan \\
dengan \\
pemecahan \\
yang \\
bijaksana
\end{tabular} & $\begin{array}{l}\quad \text { Subyek } \\
\text { mampu } \\
\text { memecahkan } \\
\text { masalah } \\
\text { pribadinya } \\
\text { dengan baik }\end{array}$ & $\sqrt{ }$ \\
\hline & \begin{tabular}{l}
\multicolumn{1}{c}{ Dapat } \\
mengobati \\
hati yang \\
tersakiti
\end{tabular} & $\begin{array}{c}\text { Subyek } \\
\text { jarang merasa } \\
\text { gundah gulana }\end{array}$ & $\sqrt{ }$ \\
\hline & $\begin{array}{l}\text { Memper } \\
\text { baiki akhlak } \\
\text { yang buruk }\end{array}$ & \begin{tabular}{l}
\multicolumn{1}{c}{ Subyek } \\
menjadi \\
pribadi yang \\
baik setelah \\
membaca \\
Alquran
\end{tabular} & $\sqrt{ }$ \\
\hline
\end{tabular}

Tabel 4 Variabel: Membaca Alquran

Berdasaran hasil dari observasi di lapangan dapat disimpulkan bahwa subyek yang bernama HD telah memenuhi kriteria yang telah ditentukan oleh peneliti. Ketiga indikator di atas telah terjawab dan dapat ditarik kesimpulan bahwa subyek mampu menyelesaikan permasalahan pribadinya dengan baik dengan pemecahan yang bijaksana. Tentunya ini merupakan implikasi dari pemahaman ayat Alquran dengan baik. Kemudian dengan membaca Alquran subyek jarang merasa gelisah atau gundah gulana, dikarenakan hati yang selalu ingat kepada Allah dan Alquran sebagai penawar hati yang gelisah. Dampak yang paling besar adalah peran membaca Alquran mampu memperbaiki akhlak yang buruk terlebih merubah pribadi menjadi lebih baik.

Adapun aspek yang ingin diuji oleh peneliti dengan menggunakan metode wawancara berjumlah satu, yaitu aspek fadhilah membaca Alquran.

\begin{tabular}{|l|l|l|l|l|}
\hline No & Aspek & Indikator & Pertanyaan & Respon \\
\hline .1 & $\begin{array}{l}\text { Fadhilah } \\
\text { membaca } \\
\text { Alquran }\end{array}$ & $\begin{array}{l}\text { Dapat } \\
\text { memupuk } \\
\text { karakter }\end{array}$ & $\begin{array}{l}\text { Apakah } \\
\text { menurutmu } \\
\text { dengan } \\
\text { membacaAl } \\
\text { quran dapat } \\
\text { memupuk } \\
\text { karakter? }\end{array}$ & $\begin{array}{l}\text { Tentu, } \\
\text { karena } \\
\text { Alquran } \\
\text { memiliki } \\
\text { sifat ihsan } \\
\text { yaitu } \\
\text { setiap kita } \\
\text { beribadah } \\
\text { kepada- } \\
\text { Nya } \\
\text { seakan }\end{array}$ \\
& & & & \\
& & Dapat & & \\
\end{tabular}

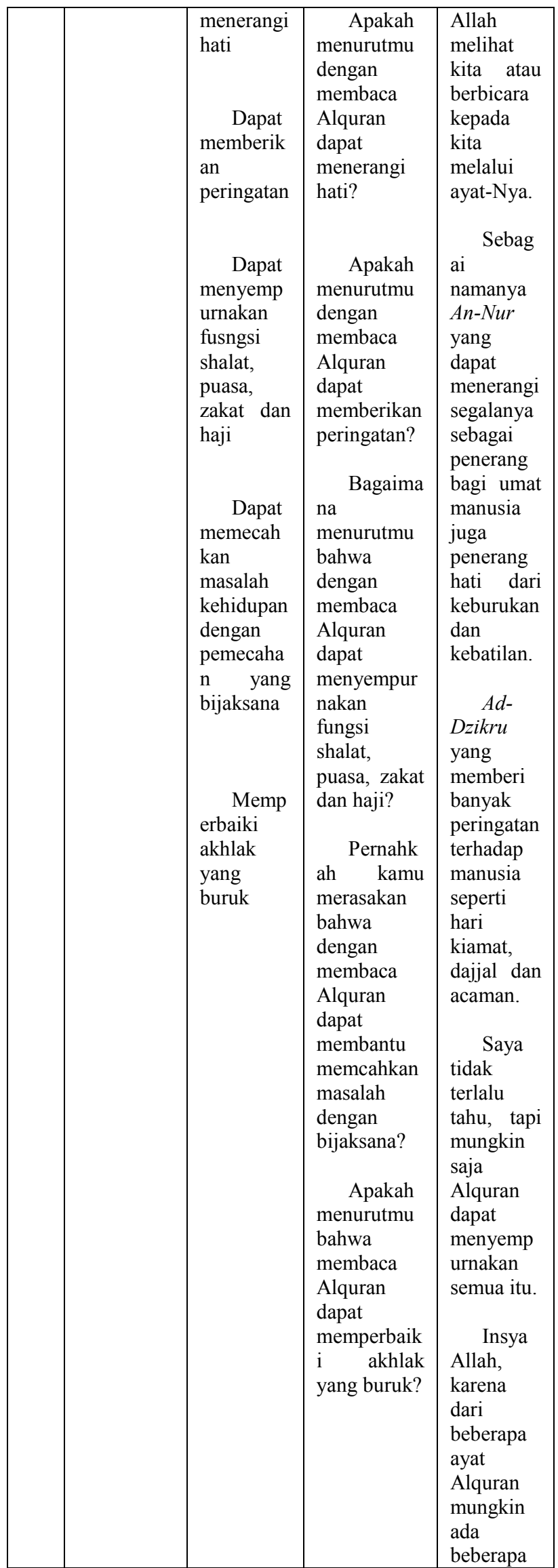



Barat)

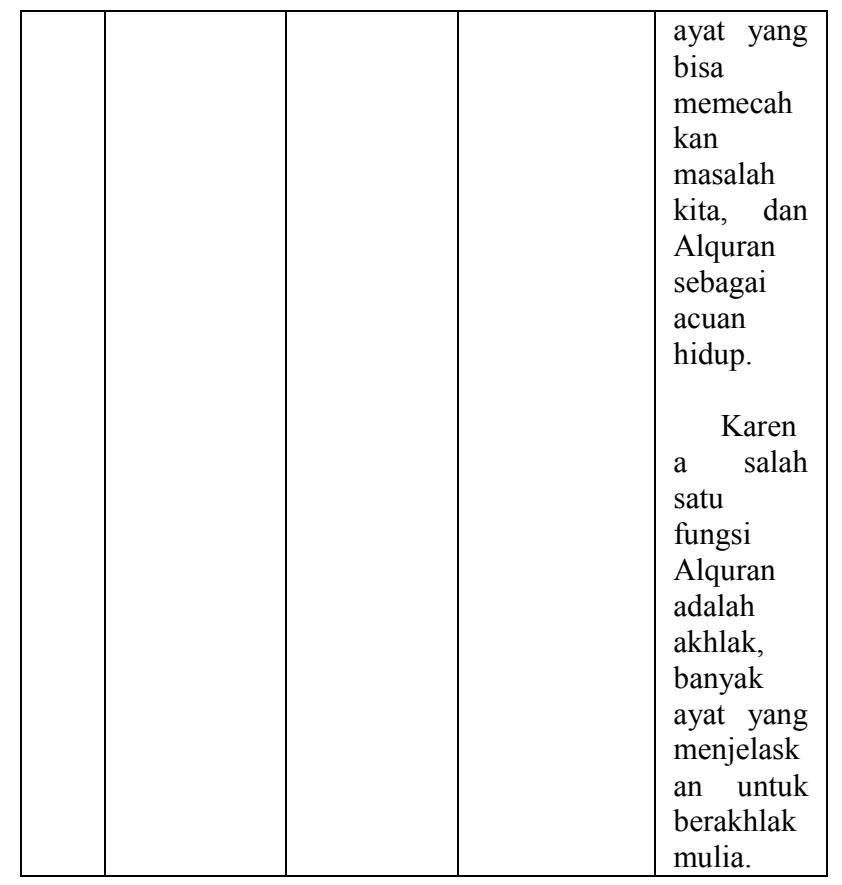

Tabel 5 Variabel: Membaca Alquran

HD siswa kelas III SMP mengatakan bahwa membaca Alquran dapat memupuk, menerangi, mengobat dan membimbing karakter agar tidak keluar dari fitrah yang sesungguhnya yaitu menyembah Allah, karena sifat Alquran sebagai as-syifa (penyembuh), al-Furqan (pembeda), dan al-Huda (petunjuk) umat manusia, sehingga manusia yang memiliki hati yang gelisah akan terobati jika membaca Alquran dengan khidmat, khusyuk dan Ikhlas. Kemudian juga Alquran dapat menerangi karakter dan sebagai penerang hidup sehingga manusia memiliki pedoman hidup yang benar.

Alquran dapat memberi peringatan jika kita membacanya dengan memahami ayatnya, dan selain itu pula manusia akan terbantu jika memiliki masalah hidup yang sulit maka dengan membaca Alquran kita manusia akan mendapatkan pertolongan dari Allah Swt melalui ayat-Nya yang mampu memberikan nasihat baik. Namun sayangnya subyek belum mengetahui bahwa Alquran dapat menyempurnakan fungsi shalat, puasa, zakat dan haji.

\section{a. A A (Kelas IX)}

Subyek yang kedua untuk memperoleh data mengenai fadhilah membaca Alquran siswa putra yang mengikuti pengajian al-Qur'an adalah AA siswa kelas III SMP. Aspek yang dicari yaitu fadhilah membaca Alquran.

Untuk observasi ada satu aspek dan tiga indikator yang ingin diketahui oleh peneliti mengenai fadhilah membaca Alquran. Hal ini bertujuan untuk mempermudah mencari jawaban masalah.

Berdasaran hasil dari observasi di lapangan dapat disimpulkan bahwa subyek yang bernama AA tidak memenuhi kriteria yang telah ditentukan oleh peneliti. Ketiga indikator di atas tidak terjawab dan hanya satu yang terjawab sehingga dapat ditarik kesimpulan bahwa subyek tidak mampu menyelesaikan permasalahan pribadinya dengan baik dengan pemecahan yang bijaksana, tentunya implikasi dari pemahaman ayat Alquran tidak berjalan dengan baik. Kemudian dengan membaca Alquran subyek jarang merasa gelisah atau gundah gulana, dikarenakan hati yang selalu ingat kepada Allah dan Alquran sebagai penawar hati yang gelisah. Dampak yang paling besar adalah peran membaca Alquran mampu memperbaiki akhlak yang buruk terlebih merubah karakter pribadi menjadi lebih baik namun sayangnya ini tidak berlaku untuk subyek IS mungkin dikarenakan kurangnya pemahaman dari ayat Alquran yang dibacanya.

Adapun aspek yang ingin diuji oleh peneliti dengan menggunakan metode wawancara berjumlah satu, yaitu aspek fadhilah membaca Alquran.

Subyek yang kedua bernama AA siswa kelas III SMP mengatakan bahwa membaca Alquran dapat memupuk karakter. Hal itu sudah tertera di dalam Alquran sendiri bahwa kandunganya berfungsi sebagai penerang hati dan karakter baik yang bersih maupun yang kotor.

Dengan membaca Alquran pula nasihat hidup untuk mendapatkan ketenangan yang hakiki yang berujung kepada kebahagiaan hidup harus didasari dengan keimanan dan ketakwaan yang total, agar rintangan dan 

Barat)

halangan hidup dapat teratasi dengan baik yang sesuai dengan syariat. Selain itu pula, subyek mengatakan bahwa membaca Alquran dapat menerangi hati dan memberikan peringatan agar terhindar dari marabahaya. Dengan membaca Alquran pula dapat menyempurnakan fungsi shalat, puasa, zakat dan haji manusia agar mempunyai akhlak yang baik dan menjadi hamba yang taat terhadap aturan Allah Swt.

\section{b. M (Kelas IX)}

Subyek yang ketiga untuk memperoleh data mengenai fadhilah membaca Alquran siswi putri yang mengikuti Pengajian al-Qur'an adalah MK siswi kelas III SMP. Aspek yang dicari yaitu fadhilah membaca Alquran.

Untuk observasi ada satu aspek dan tiga indikator yang ingin diketahui oleh peneliti mengenai fadhilah membaca Alquran. Hal ini bertujuan untuk mempermudah mencari jawaban masalah.

Berdasaran hasil dari observasi di lapangan dapat disimpulkan bahwa subyek yang bernama MK tidak memenuhi kriteria yang telah ditentukan oleh peneliti. Ketiga indikator di atas tidak terjawab dan hanya satu yang terjawab sehingga dapat ditarik kesimpulan bahwa subyek tidak mampu menyelesaikan permasalahan pribadinya dengan baik dengan pemecahan yang bijaksana, tentunya implikasi dari pemahaman ayat Alquran tidak berjalan dengan baik. Kemudian dengan membaca Alquran subyek jarang merasa gelisah atau gundah gulana, dikarenakan hati yang selalu ingat kepada Allah dan Alquran sebagai penawar hati yang gelisah. Dampak yang paling besar adalah peran membaca Alquran mampu memperbaiki akhlak yang buruk terlebih merubah pribadi menjadi lebih baik namun sayangnya ini tidak berlaku unuk subyek MK mungkin dikarenakan kurangnya pemahaman dari ayat Alquran yang dibacanya.

Adapun aspek yang ingin diuji oleh peneliti dengan menggunakan metode wawancara berjumlah satu, yaitu aspek fadhilah membaca Alquran.

Subyek yang ketiga bernama MK siswa kelas III SMP mengatakan bahwa membaca
Alquran dapat memupuk karakter karena Alquran adalah kalamullah yang mengandung arti dan motivasi untuk hidup manusia. Kemudian dengan membaca Alquran pula manusia akan mengetahui larangan-larangan Allah untuk hambanya. Jika kita membacanya dengan baik dan bernar serta khidmat maka kita akan terbantu dalam menyelesaikan permasalahan hidup dengan bijaksana.

Di dalam Alquran banyak kisah-kisah inspiratif yang dapat diambil himahnya dan kita terapkan di kehidupan sehari-hari dengan harapan menjadi pribadi yang isalmi. Dengan itu kita akan menjadi manusia yang berakhlak mulia. Namun sayangnya subyek kurang mengetahui bahwa Alquran dapat menyempurnakan fungsi shalat, puasa, zakat dan haji.

\section{c. D M (KelasX)}

Subyek yang keempat untuk memperoleh data mengenai fadhilah membaca Alquran siswa putra yang mengikuti Pengajian alQur'an adalah DM siswa kelas I SMA. Aspek yang dicari yaitu fadhilah membaca Alquran.

Untuk observasi ada satu aspek dan tiga indikator yang ingin diketahui oleh peneliti mengenai fadhilah membaca Alquran. Hal ini bertujuan untuk mempermudah mencari jawaban masalah.

Berdasaran hasil dari observasi di lapangan dapat disimpulkan bahwa subyek yang bernama DM tidak memnuhi kriteria yang telah ditentukan oleh peneliti. Ketiga indikator di atas tidak terjawab dan hanya satu yang terjawab sehingga dapat ditarik kesimpulan bahwa subyek tidak mampu menyelesaikan permasalahan pribadinya dengan baik dengan pemecahan yang bijaksana, tentunya implikasi dari pemahaman ayat Alquran tidak berjalan dengan baik. Kemudian dengan membaca Alquran subyek masih merasa gelisah atau gundah gulana, dikarenakan hati yang tidak ingat kepada Allah dan Alquran. Dampak yang paling besar adalah peran membaca Alquran mampu memperbaiki akhlak yang buruk terlebih merubah pribadi menjadi lebih baik dan itu berlaku untuk subyek DM. 

Barat)

Adapun aspek yang ingin diuji oleh peneliti dengan menggunakan metode wawancara berjumlah satu, yaitu aspek fadhilah membaca Alquran.

Subyek yang ke empat bernama DM siswa kelas I SMA mengatakan bahwa membaca Alquran dapat memupuk karakter dan menerangi hati. Kemudian juga dengan membaca Alquran kita akan tahu larangan dan perintah Allah melalui kalam-Nya. Dengan demikian fungsi shalat, puasa, zakat dan haji kita akan sempurna, sehingga hal itu berdampak pada pola hidup kita untuk menjadi lebih baik dan memiliki perangai yang baik pula.

\section{d. R (Kelas X)}

Subyek yang keempat untuk memperoleh data mengenai fadhilah membaca Alquran siswi putri yang mengikuti Pengajian alQur'an adalah RO siswa kelas I SMA. Aspek yang dicari yaitu fadhilah membaca Alquran.

Untuk observasi ada satu aspek dan tiga indikator yang ingin diketahui oleh peneliti mengenai fadhilah membaca Alquran. Hal ini bertujuan untuk mempermudah mencari jawaban masalah.

Berdasaran hasil dari observasi di lapangan dapat disimpulkan bahwa subyek yang bernama RO telah memenuhi kriteria yang telah ditentukan oleh peneliti. Ketiga indikator di atas telah terjawab dan mampu ditarik kesimpulan bahwa subyek mampu menyelesaikan permasalahan pribadinya dengan baik dengan pemecahan yang bijaksana, tentunya ini merupakan implikasi dari pemahaman ayat Alquran dengan baik. Kemudian dengan membaca Alquran subyek jarang merasa gelisah atau gundah gulana, dikarenakan hati yang selalu ingat kepada Allah dan Alquran sebagai penawar hati yang gelisah. Dampak yang paling besara adalah peran membaca Alquran mampu memperbaiki akhlak yang buruk terlebih merubah pribadi menjadi lebih baik.Adapun aspek yang ingin diuji oleh peneliti dengan menggunakan metode wawancara berjumlah satu, yaitu aspek fadhilah membaca Alquran.
Hasil yang kelima yang diperoleh dari subyek yang bernama RO siswa kelas I SMA mengatakan bahwa membaca Alquran dapat memupuk karakter dan menerangi hati, karena Alquran adalah kitab yang suci yang dapat menghilangkan rasa gelisah yang membuat hidup kita menjadi tidak bahagia. Selain itu pula Alquran dapat memberikan peringatan jika membacanya dibarengi dengan kemampuan menterjemahkan arti dari ayat yang dibaca dan tentunya harus didasari dengan keimanan dan ketakwaan yang total.

Membaca Alquran menyempurnakan fungsi shalat, puasa, zakat dan haji serta memberikan arahan positif untuk menjalani hidup guna menjadi pribadi yang baik. Oleh karena itu membaca Alquran memiliki implikasi yang besar terhadap hidup manusia jika dibarengi dengan keimanan, terutama Alquran dapat menerangi hati dan memupuk karakter untuk meraih ketenangan karakter kebahagiaan yang abadi.

Sebagaimana telah dijelaskan di atas bahwa keberadaan karakter seseorang akan dapat diketahui melalui sikap, perilaku, atau penampilannya, yang dengan fenomena itu seseorang dapat dinilai atau ditafsirkan bahwa kondisi penjiwaan atau rohaniyah dalam keadaan baik, sehat, benar, atau tidak. ${ }^{12}$ Seorang hamba Allah SWT akan dapat mencapai tingkat penjiwaan atau mental yang sempurna, yaitu integritasnya:

Karakter muthmainnah (yang tentram) adalah karakter yang senantiasa mengajak kembali kepada fitrah Ilahiyah Tuhannya.

Karakter radhiyah, (karakter yang meridhai) adalah karakter yang tulus, bening dan lapang dada terhadap Allah Swt, terhadap kebijaksanaan, qudrat dan iradat-Nya. Karakter inilah yang mendorong diri bersikap lapang dada, tawakkal, tulus ikhlas dan sabar dalam mengaplikasikan seluruh perintah-Nya, menjauhi segala larangan-Nya dan menerima

\footnotetext{
12 Hamdani Bakran Adz-Dzaky, Konseling dan Psikoterapi Islam (Yogyakarta: Fajar Pustaka Baru, 2001), 335.
} 

Barat)

dengan lapang dada segala ujian dan cobaan yang datang dalam hidup dan kehidupannya.

Karakter yang mardhiyah (yang diridhai) adalah karakter yang telah memperoleh titel dan gelar kehormatan dari Allah Swt. Dan dengan gelar itu keimanan, keislaman, keihsanan, dan ketauhidannya tidak akan pernah mengalami erosi, dekandensi, dan distorsi.

Sesuai dengan hasil penelitian yang peneliti lakukan dengan menggunakan metode observasi dan wawancara terhadap siswa di SMP swasta non-agama yang mengikuti kelompok pengajian al-Qur'an. Dari penjelasan di atas bahwa karakter yang tenteram (muthmainnah) adalah karakter yang senantiasa mengajak sesamanya untuk kembali kepada fitrah ilahiyyah.

Dari kelima subyek di atas menunjukkan bahwa empat diantaranya mengatakan pernah mengajak temannya untuk membaca Alquran, dan satu diantaranya mengatakan jarang. Sebagaimana diketahui bahwa membaca Alquran adalah media untuk berkomunikasi dengan Allah Swt dan untuk menjadi hamba yang taat dan bertaqwa. Selain itu pula ada beberapa subyek yang terindikasi memiliki karakter yang ridha karena mensyukuri dan tabah jika tertimpa sesuatu yang tidak diinginkannya.

Kemudian untuk mencapai derajat membaca Alquran yang bisa menjadi obat karakter atau tidak hanya seperti membaca koran (tidak membekas di hati). Memang bukan sesuatu hal yang mudah paling tidak harus menghayati setiap kata dan ayat yang terdengar di telinga, karena tidak semua orang mengerti bahasa Arab. Maka dengan tawadlu dan rendah diri, sekaligus menghadirkan hari dengan menyamakan gelombang hati dengan suara Alquran, Insya Allah bisa merasakan kelezatan membaca Alquran, selain itu harus mengikuti cara-cara atau metode-metode yang benar sehingga Alquran benar-benar menjadi obat bagi hati yang gundah atau cemas. ${ }^{13}$ Adapun metode-metodenya sebagai berikut:

Mengikuti adab akhlaqiah membaca Alquran, diantaranya:

Mempunyai wudhu, Kelima subyek mengatakan bahwa mereka berwudhu sebelum membaca Alquran. Hal itu bertujuan untuk membersihkan diri dari hadats kecil guna menjaga kesucian Alquran.

Membaca ta'awudz, Kelima subyek tersebut mengatakan bahwa mereka membaca ta'awudz ketika hendak membaca Alquran. Hal itu bertujuan untuk menghindari godaan jin dan setan yang suka mengganggu manusia yang ingin mendekatkan diri kepada Allah Swt.

Hendaknya tidak membaca terlalu cepat, Syah Abdul Aziz r.a menerangkan bahwa makna dasarnya adalah membaca dengan baik dan jelas. Kelima subyek di atas memiliki kemampuan yang baik ketika membaca Alquran dalam hal ini mereka membaca Alquran secara tartil (teratur).

Bacalah dengan suara yang indah, dengan memperindah suara dalam membaca Alquran hati mudah tergugah dan tertarik, sehingga ikut hanyut dalam setiap firman-Nya. ${ }^{14}$ Dari kelima subyek diatas menunjukkan bahwa mereka membaca Alquran dengan nada murotal dan lancar, namun untuk kategori indah dan merdu tentunya masih belum dikatakan iya.

Berusaha untuk menangis. Dari kelima subyek diatas bahwa tidak ditemukannya metode ini, karena untuk bisa sampai menangis diperlukan tingkat pemahaman ayat yang lauar biasa dan keimanan yang kuat.

Jika ditinjau dari berbagai segi, membaca Alquran dapat memupuk karakter, memberi tahu manusia yang harus dilaksanakannya dan membangkitkan berbagai nilai yang diinginkan dalam penyucian karakter.

\footnotetext{
13 Maulana Muhammad Zakariyya al-Kandhalawi, Fadhail Amal, 338.

14 Fatihuddin Abul Yasin, Terapi Pengobatan Penyakit Hati (Surabaya: Terbit Terang, 2002), 85.
} 

Barat)

Membaca Alquran dapat menerangi hati dan memberikan peringatan kepadanya. Membaca Alquran juga menyempurnakan fungsi shalat, zakat, puasa, dan haji dalam mencapai derajat kehambaan kepada Allah Swt. membaca Alquran menuntut penguasaan yang sempurna mengenai hukum-hukum tajwid dan komitmen harian untuk mewiridkan Alquran. Alquran akan dapat berfungsi dengan baik jika dalam membacanya disertai dengan adab-adab batin dalam perenungan, khusyuk dan tadabbur.

Sebagaiamana data yang diperoleh dari kelima subyek di atas menunjukkan bahwa membaca Alquran dapat memberikan dampak yang baik jika disertai dengan keimanan dan keyakinan yang kuat. Oleh karena itu membaca Alquran harus dijadikan momen untuk berdialog dengan Allah agar mendapatkan ridha-Nya dan meningkatkan ketenangan karakter agar selalu menjadi insan yang bahagia baik di dunia maupun di Akhirat.

Penulis melakukan wawancara terhadap para orang tua keluarga petani tentang persepsi mereka terhadap pendidikan anak-anaknya. Timbulnya persepsi baik atau buruk dari orang tua dipengaruhi oleh beberapa faktor diantaranya:

Pertama. Pendidikan Orang Tua. Pendidikan mempengaruhi tingkat persepsi orang tua. Pendidikan tinggi dan rendah akan mempengaruhi pandangan terhadap pendidikan terhadap anaknya. Artinya semakin tinggi pendidikan orang tua dan pendapatan keluarga akan semakin baik persepsinya tentang pendidikan terhadap anaknya.

Orang tua di Desa Sukamaju, sebagian besar memiliki tingkat pendidikan formal yang rendah. Mereka hanya mengikuti berbagai kegiatan-kegiatan non formal yang diadakan di masyarakat, misalnya melalui kegiatan ceramah keagamaan yang ada di masyarakat di Desa Sukamaju. Oleh karena itu, orang tua di daerah Sukamaju ini memiliki kesadaran yang rendah terhadap pendidikan anaknya. Bagi mereka pendidikan hanya cukup sampai bisa membaca dan menulis, dan tidak perlu sekolah tinggi. Orang tua petani Desa Sukamaju yang memiliki anak putus sekolah percaya bahwa kesuksesan seseorang tidak ditentukan oleh seberapa tinggi pendidikan yang ditempuh, sehingga tidak terlalu penting menyekolahkan anak hingga ke jenjang pendidikan menengah.

Sebagaimana hasil wawancara penulis dengan Bapak Edi, ${ }^{15}$ menuturkan bahwa:

"Bagi saya, menyekolahkan anak tidak perlu tinggi-tinggi cukup sampai anak dapat membaca dan menulis saja. Karena dengan dapat membaca dan menulis, maka kita tidak akan tertipu dalam kehidupan. Andaipun sekolah tinggi-tinggipun, pada akhirnya hanya mencari kerja. Jadi lebih baik bekerja saja sejak kecil supaya dapat uang. Anak saya berhenti sekolah terus sekarang membantu saya bersawah. Ditambah lagi saya yang sudah tua, tidak ada lagi yang membantu saya, dan juga untuk mencari uang sebelum musim panen".

Kedua. Ekonomi Rumah Tangga. Kemampuan ekonomi sebagian besar warga masyarakat petani di Desa Sukamaju paspasan. Mereka adalah para petani buruh dan serabutan. Penghasilan hanya cukup untuk makan sehari-hari, bahkan terkadang kurang. Hal ini sangat mempengaruhi persepsi mereka terhadap pendidikan anaknya. Artinya akibat keadaan ekomoni yang rendah, maka pandangannya terhadap pendidikan menjadi rendah pula. Bagi masyarakat Desa Sukamaju, yang penting bekerja untuk menghasilkan uang. Bahkan bekerja yang mereka lakukan sebagai petani diwariskan kepada anakanaknya, sehingga secara turun temurun menjadi petani.

Keluarga petani Desa Sukamaju yang memiliki anak putus sekolah pada umumnya memiliki pendapatan ekonomi yang rendah, sehingga memerlukan bantuan dari anak untuk menambah penghasilan keluarga demi memenuhi kebutuhan-kebutuhan keluarga. Oleh karena itu, orang tua yang memiliki pendidikan dan pendapatan yang rendah

\footnotetext{
15 Yudi, pendidikan anak-anak di Desa Sukamaju, 10 Juni 2018, Desa Sukamaju-Kabupaten Cianjur.
} 

Barat)

memiliki persepsi yang lebih rendah tentang pendidikan bagi anaknya dibandingkan dengan keluarga yang memiliki pendidikan dan pendapatan lebih tinggi yang pada umumnya dapat menyekolahkan anak-anak mereka hingga ke jenjang sekolah yang lebih tinggi. Sebagaimana hasil wawancara penulis dengan Bapak Yudi, ${ }^{16}$ mengatakan:

"Pendidikan itu memang penting, tetapi bagi saya yang tidak mampu secara ekonomi bagaimana bisa melanjutkan sekolah untuk anak-anak saya. Kalau nanti sekolah pada akhirnya bertujuan untuk mencari pekerjaan, untuk apa sekolah tinggi-tinggi. Lebih baik tidak sekolah tetapi langsung bekerja agar menghasilkan uang untuk keperluan seharihari. Bukan saya saja warga sini yang anaknya tidak melanjutkan sekolah. Rata-rata karena uang untuk bayar sekolah terlalu tinggi. Yah kalau sampai tingkat SMP memang tidak bayar, tetapi kan perlu ongkos dan lainnya, tetap memerlukan biaya".

Ketiga. Kesadaran Orang Tua. Kesadaran orang tua tentang pentingnya pendidikan dapat membentuk persepsi seseorang. Jika memiliki kesadaran yang tinggi, maka persepsi terhadap pendidikan anak semakin baik.

\section{SIMPULAN}

Dalam penelitian ini, para peneliti menempatkan diri sebagai the insider yang berusaha sejauh mungkin melakukan empati (atau memproyeksikan diri dalam peran dan persepsi obyek yang diteliti) agar bisa sebaik mungkin merefleksikan penghayatan subyektif dari obyek yang diteliti.

Dari paparan data dan analisis yang telah diuraikan oleh peneliti maka dapat ditarik kesimpulan bahwa:

Metode membaca Alquran siswa yang mengikuti Pengajian Al-Qur'an sudah sesuai dengan Syariat yang ditentukan, yaitu: 1) Mengikuti adab akhlaqiah membaca Alquran, diantaranya: a) Berwudhu sebelum membaca Alquran, b) Membaca ta'awudz ketika hendak membaca Alquran, c) Membaca Alquran

\footnotetext{
${ }^{16}$ Yudi.
}

dengan tartil, dan d) Berusaha semampunya untuk memahami ayat yang dibaca. 2) Mengikuti adab batiniah membaca Alquran, diantaranya: a) Memahami arti ayat yang dibaca, b) Akhlak ketika membaca Alquran, c) Hati yang mengagungkan Allah SWT, d) Hati yang menjungjung tinggi Alquran, e) Merasakan bahwa Allah sedang berbicara. Dengan menggunakan metode yang benar maka aktivitas membaca Alquran bukan sekedar aktivitas rutinan, melainkan menjadi aktivitas ibadah yang dapat memberikan dampak positif bagi kehidupan.

Kondisi karakter siswa putra di Sekolah Menengah Non-Agama di Jawa Barat yang mengikuti Pengajian Al-Qur'an secara bathiniah berada pada tingkat muthmainnah dan secara lahiriah berada pada kondisi karakter yang adaptif, komunikatif dan sosial.

Peran membaca Alquran terhadap penguatan karakter siswa yang mengikuti Pengajian Al-Qur'an sangat besar dan memberikan dampak positif terhadap kondisi karakter siswa seperti menjadi penunjuk arah dan penasihat hidup dalam sehari-hari. Dengan demikian, membaca Alquran di sekolah-sekolah non-agama di Jawa Barat bukan kegiatan yang biasa melainkan menjadi media untuk berkomunikasi dengan Allah Swt guna menguatkan karakter.

Adapun saran yang dapat penulis berikan adalah sebagai berikut:

Hasil penelitian ini diharapkan mampu menjadi bahan evaluasi untuk meningkatkan kualitas siswa dalam membaca Alquran dan implikasinya pada kehidupan sehari-hari. Sayang, karena bersifat ekstra kurikuler, yang berarti bersifat sukarela, tidak banyak siswa yang terjaring oleh kegiatan ini.

Sangat disayangkan bahwa program literasi al-Qur'an itu hanya bersifat ekstra kurikuler di sekolah-sekolah non-agama tersebut, akan lebih baik jika kemudian derajatnya diangkat ke kelas yang lebih kurikuler, yang bersifat wajib. Karena membaca al-Qur'an nampaknya lebih efektif untuk penguatan karakter daripada mata pelajaran agama yang hanya bersifat kognitif belaka. 


\section{DAFTAR PUSTAKA}

Asep S Muhtadi, dan Agus Ahmad Safei. AlQur'an Kitab Kehidupan. Vol. 1. Bandung: LPTQ ProvinsiJawa Barat, 2004.

Fatihuddin Abul Yasin. Terapi Pengobatan Penyakit Hati. Surabaya: Terbit Terang, 2002.

Fuji Pratiwi. "Literasi Alquran Siswa SMA Belum Menggembirakan." Republika, 5 Desember 2016. www.republika.co.id.

Hamdani Bakran Adz-Dzaky. Konseling dan Psikoterapi Islam. Yogyakarta: Fajar Pustaka Baru, 2001.

Kirsch, I.S. "Adult reading practices for work and leisure." Adult Education Quarterly 34 (1984): 213-232.

Matsuura Koichiro. "Intangible Cultural Heritage was incorporated to Balence The Euro- centrism," t.t.
Maulana Muhammad Zakariyya alKandhalawi. Fadhail Amal. Bandung: Pustaka Ramadhan, 2001.

M.Bamberger. Integrating Quantitative and Qualitative Research in Devlopment Project. Wasington DC: Directions in Devlopment, 2000.

Moleong. Metodologi Penelitian Kualitatif. Bandung: CV. Remaja Rosdakarya, 1998.

Nur Subhan. Energi Ilahi Tilawah. Jakarta: Republika, 2012.

S.Nasution. Berbagai Pendekatan dalam proses Belajar-mengajar. Jakarta: Bumi Aksara, 1982.

Yudi. pendidikan anak-anak di Desa Sukamaju, 10 Juni 2018. Desa SukamajuKabupaten Cianjur.

Yusuf al-Qardhawi. Berinteraksi dengan alQur'an. Diterjemahkan oleh Abbdul Hayyie al-Kattan. 1 ed. Jakarta: Gema Insani Press, 1999. 